\title{
A conceptualization of e-risk perceptions and implications for small firm active online internationalization
}

\author{
Noemi Pezderka, Rudolf R. Sinkovics* \\ The University of Manchester, Manchester Business School, Booth Street West, Manchester M15 6PB, United Kingdom
}

\section{A R T I C L E I N F O}

\section{Article history:}

Received 29 May 2009

Received in revised form 13 June 2010

Accepted 15 June 2010

\section{Keywords:}

Active online internationalization

Conceptualization

E-risk

International business

Online

Risk

SME

\begin{abstract}
A B S T R A C T
A sound conceptualization of international e-risks has grown in demand, because of the increasing penetration of the Internet, and specifically the enabling-facility of the Internet technology for small firms. Yet, to date, there has been no study explicitly attempting to build an international business risk framework for the online environment, nor to explain online internationalization decisions. The purpose of the present paper is threefold, (1) to combine and complement the existing traditional international risk constructs and the emerging views on e-business risks into a comprehensive and unified international risk framework for the online context; (2) to develop propositions regarding SMEs' active online internationalization decisions by drawing on Dunning's OLI framework; and (3) to explore the online-offline risk trade-off inherent in online internationalization decisions by integrating the e-risk framework into the eclectic paradigm.
\end{abstract}

Crown Copyright (c) 2010 Published by Elsevier Ltd. All rights reserved.

\section{Introduction}

With growing competitive pressures, companies are increasingly deploying the Internet as a strategic tool (Ching \& Ellis, 2004; Porter, 2001). The use of information and communication technology (ICT) not only impacts on communication, control and collaboration processes (Jean \& Sinkovics, 2010; Jean, Sinkovics, \& Cavusgil, 2010; Jean, Sinkovics, \& Kim, 2008; Jean, Sinkovics, \& Kim, 2010; Yamin \& Sinkovics, 2007), it also promises a fast-track option of international expansion (Sinkovics \& Penz, 2005). The deliberate use of ICT for internationalization purposes is termed "internetalization" by Bell, Deans, Ibbotson, and Sinkovics (2001) and "active online internationalization" (AOI) by Yamin and Sinkovics (2006). It is a form of foreign market entry which takes place "in the virtual rather than the real or spatial domain" (Yamin \& Sinkovics, 2006, p. 340). Consequently, companies opting for this mode of entry have no equity based market presence in the host country. While active online internationalization is possible for both large and small firms, especially in the initial stages of internationalization, small firms are more likely to adopt this mode of market entry (Bennett, 1997). Thus, in this paper we exclusively focus on small and medium-sized firms engaging in AOI. To date, research on the phenomenon of active online internationalization is limited.

International business (IB) deals with a multitude of contingencies in its external environment and is thus considered inherently risky (Shrader, Oviatt, \& Phillips McDougall, 2000). Therefore, the online analogue to traditional physical exchange also exposes firms to an array of risks (Scott, 2004; Viehland, 2001; Wat, Ngai, \& Cheng, 2005). While some of these risks are only relevant in the online context, others have their origins in the traditional international business environment. Even though many risks belonging to the latter category are regarded less relevant for companies predominantly doing business in the virtual domain, they need to be carefully examined, as due to their latent nature they might still affect these

\footnotetext{
* Corresponding author. Tel.: +44 161306 8980; fax: +44 1612756464.

E-mail addresses: Noemi.Pezderka@postgrad.mbs.ac.uk (N. Pezderka), Rudolf.Sinkovics@manchester.ac.uk (R.R. Sinkovics).

URL: http://www.personal.mbs.ac.uk/rsinkovics/
} 
companies in a different and/or less visible way. Understanding international risk in both its traditional and virtual forms is crucial for three reasons: (a) the conscious and controlled handling of risks can be seen as a capability and thus represents an important source of sustainable competitive advantage (Barney, 1991); (b) the lack of a thorough risk assessment can not only deprive a business of future profits but might also lead to complete business failure; (c) companies' entry mode choice has been found to be contingent on the level of perceived risk in the target country (Brouthers, 1995). Despite this background, however, the international business literature not only lacks an extensive international e-risk framework, there is also little known about the factors influencing online internationalization. While there are studies speculating on the potential advantages and disadvantages of e-commerce adoption, as well as on the Internet's impact on the internationalization process and existing export marketing theories (e.g. Gregory, Karavdic, \& Zou, 2007; Karavdic \& Gregory, 2005), the literature lacks a conceptual framework that explicitly details the reasons for online market entry choice over more traditional entry modes.

This paper has three main objectives. Firstly, it aims at combining and complementing the existing traditional international risk constructs and the emerging views on e-business risks into a comprehensive and unified international risk framework for the online context. Secondly, it seeks to develop propositions for future research which help to explain why SMEs' opt for active online internationalization. For this, we draw on Dunning's (1980) OLI framework and more recent work that examined the extent to which the eclectic paradigm of international production, and its composite theories, can help in the online domain (Dunning \& Wymbs, 2001). Thirdly, it endeavors to explore the online-offline risk trade-off inherent in online internationalization decisions by integrating the e-risk framework into the eclectic paradigm. The OLI framework was selected for three distinct reasons, i.e. (1) its explanatory value for traditional entry mode choice has a sound track-record (e.g. Brouthers, Brouthers, \& Werner, 1996; Dunning \& Wymbs, 2001); (2) its relevance has been successfully tested for SME entry mode decisions; and (3) traditional international (offline) risks are a building block of the existing OLI framework. To this end, integrating e-risks in the existing OLI framework helps to demonstrate the online-offline risk trade-off in internationalization decisions. The main contributions of the paper thus are the conceptualization of e-risks in international business and the exploration of the latent online-offline risk trade-off in small firm online internationalization decisions by drawing on the eclectic paradigm.

The structure of the paper is as follows: Section 2 starts with a theoretical discussion of the role of ICT for small versus large firm internationalization followed by the introduction of the e-risk framework and its implications for small firm internationalization. Section 3 presents our propositions for future research. Section 4 concludes by considering implications and limitations.

\section{Conceptual background}

\subsection{The role of ICT for small and large firm internationalization}

The Internet as an alternative means to physical market entry is expected to be more relevant for smaller firms than large multinational enterprises (MNEs) for several reasons. Small and medium enterprises (SMEs) are inherently resource-poorer than large corporations and their vulnerability threshold to business failure is lower. Consequently, while for large MNEs, failure in one country can still be compensated for by successes in other countries, for SMEs such a failure is most likely to result in business closure (Buckley, 1989; Welsh \& White, 1981). On-site knowledge development and learning is arguably a major driver of MNE internationalization (Forsgren, 2002; Hadjikhani \& Johanson, 2002), while SMEs will utilize ICT to compensate for experiential learning opportunities (Jean, 2007). Another implication of smaller firms' limitations in terms of resource endowments is their constrained ability to make significant resource commitments in a host country for the purpose of initial relationship building or uncertainty reduction (Figureira-de-Lemos, Johanson, \& Vahlne, 2010). While large MNEs benefit from direct physical market presence via their subsidiaries (Andersson, Forsgren, \& Holm, 2001) and although the fact that their subsidiaries are embedded in the local country's context provides them with an "advantage of multinationality" (Yamin, 2002), they lose some of their flexibility due to their large size (Moini \& Tesar, 2005) and organizational inertia (Kelly \& Amburgey, 1991). Although ICT has the potential to reduce MNEs' internalization propensity (Rangan \& Sengul, 2009), their ICT adoption is still not likely to result in a shift from a physical to a mainly virtual presence. In cases where ICT use reduces internal transaction costs or enhances internal monitoring, it may even strengthen the multinational's internalization process (Rangan \& Sengul, 2009).

Small companies, on the other hand, are suggested to be able to compensate for some of their inherent disadvantages by trading off direct physical market embeddedness against strategic use of the Internet (Moini \& Tesar, 2005). They can improve flexibility by speedily engaging in parallel market entries, facilitated by information and communication technology (ICT), thus benefitting from “dilution of sequencing” in international expansion (Yamin \& Sinkovics, 2006). Yet, whether the Internet is suitable as an alternative to SMEs' physical internationalization also depends on the nature of the business and the products sold (Zaheer \& Manrakhan, 2001) as well as on industry characteristics.

\subsection{An international e-risk framework (Appendix B)}

Table 1 lists 25 risk dimensions identified in the literature, classifying them into three categories: (1) traditional IB risks contain dimensions which have their origins in the physical environment (to date, these have been excluded from emerging 
e-risk frameworks); (2) operational risks include dimensions which are typical for domestic brick-and-mortar firms as well as domestic e-businesses; (3) online media risks are unique to online media use. The second column in Table 1 identifies the core element(s) of the respective risk dimension. While the third column summarizes the main transformative effects entailed with the development and spread of ICT, the fourth column lists their implications. ${ }^{1}$

\subsection{Traditional IB risks}

Through thriving on flexibility and applying ICT in a strategically sound way, SMEs' may experience a significant competitive advantage over large corporations (Moini \& Tesar, 2005; Porter, 2001). Yet, the prospect of engaging in online internationalization, i.e. bypassing intermediaries and avoiding major foreign direct investments (FDIs) in host countries, may wrongly suggest that traditional international risks such as political and transfer risk have lost their relevance in cyberspace, and thus incentivize small and flexible organizations. A closer investigation of the core risk elements and how the new technologies have changed the nature of these reveals that their impacts still resurface, although in a transformed manner (see Table 1). This implies a distortion of risk perceptions, where operational and online media risks are perceived to be more relevant than international IB risks. This may partially be due to the prominence of the former categories in the academic and practitioner literature (e.g. Lynne, 2000; Reeves, 2000; Scott, 2004), whereas traditional IB risks are downplayed or ignored. Another reason for this limited perception is the latent nature of the comprised risk dimensions, stemming from the company's isolation from the host market (Yamin \& Sinkovics, 2006). There may be a substantial time-lag between the activation of a risk, for example the incompatibility of the company's payment system with consumer practice in a host country (Guillen, 2002; Harrison-Walker, 2002), and the materialization of its negative implications, for example revenue losses due to customer alienation. Thus the most specific aspects of e-risks belonging to this category are their latent nature and their challenging manageability. The negligence of these e-risks by SME owner-managers coupled with an overemphasis of investment in online transactions (Morgan-Thomas, 2009) without strategic alignment (Porter, 2001) might lead to severe financial losses or even business failure.

\subsection{Operational risks}

Compared to traditional IB risks, operational risks can be expected to be more salient in the online domain, not only because the e-commerce literature points at these very prominently, but because they are more easily identifiable. For example, while it may cost an e-company a tremendous amount of time and expertise to identify causes of deviances from revenue targets in the firm's international activities, operational causes such as technological reliability issues, or logistical inefficiencies show up immediately, as they have an instantaneous impact on the company's day-to-day business operations. Thus, the management of these risks is less challenging than that of traditional IB risks. Yet, operational risks are not to be neglected. Although they can be more easily detected than traditional IB risks, in a cross-border context these risk dimensions might be magnified due to governance and trust issues.

\subsection{Online media risks}

Online media risks are inherent in the use of ICT. With the exception of "physical security risk", these are the most wellknown and well-researched risk dimensions in the e-commerce literature (e.g. Scott, 2004). Despite the expeditious growth of cyber-crime (Andrijcic \& Horowitz, 2006; Braga, 2005), IT experts are continuously developing new protective technologies, such as the secure electronic transactions protocol (Scott, 2004), facilitating the control and management of online media risks. SMEs engaging in online internationalization can be expected to perceive these risks as more relevant as opposed to risk dimensions in the traditional IB risk category. This perception enables them to actively manage these risks. In the international business context the relevance of the online media risk dimension may vary depending on the host countries legal infrastructure and the education level of the user population.

\section{A proposed framework for online entry mode selection}

Given the importance of the concept of risk in firm internationalization (Dunning \& Wymbs, 2001; Figureira-de-Lemos et al., 2010; Johanson \& Vahlne, 1977), it is important to investigate the potential implications of e-risks for online internationalization. To date, studies conducted on SMEs' entry mode choices have primarily focused on traditional market entry. While Brouthers and Hennart (2007) identified sixteen different entry modes in their review of the entry mode choice literature, none of these included online market entry. Also, while single studies exist investigating the Internet's importance for SMEs' export behavior (e.g. Bennett, 1997; Hamill, 1997; Hamill \& Gregory, 1997; Moini \& Tesar, 2005; Morgan-Thomas, 2009), they do not deal with the question of why firms choose the Internet over offline channels. To this end, we found that Dunning's (2001) eclectic framework offers substantial explanatory value. Although their focus had been on large firm internationalization, Dunning and Wymbs (2001) examined the applicability of the framework to e-commerce development

\footnotetext{
${ }^{1}$ For a detailed discussion on the difference between risk and uncertainty see "Comments regarding risk and uncertainty" in the Appendix A.
} 
and concluded that it had considerable relevance. In an attempt to explain SMEs' entry mode choices, Brouthers et al. (1996), and later Nakos and Brouthers (2002), tested the predictive ability of the framework (initially designed for large firm internationalization) for small firms and found empirical support for its influence on their entry mode decisions. Most importantly, however, OLI offers a unique opportunity to illustrate how the online expansion option changes the risk landscape of small firm internationalization. As offline international risk is already an integral element of the eclectic paradigm (see Fig. 1) the integration of online risks into the framework demonstrates how the trade-off between offline and online risks may influence firms' internationalization decisions.

Arguably, an alternative theoretical base for the explanation of this entry decision could be the Uppsala model of internationalization. In their forthcoming article Figureira-de-Lemos et al. (2010) make the implicit risk/uncertainty dimension explicit and posit that the extent of a firm's resource commitment (i.e. entry mode) in a foreign market is contingent on market knowledge and perceived uncertainty in a given foreign market. We acknowledge that this is indeed a valuable extension to the Uppsala model and allows arriving at a similar theoretical argumentation regarding the initial market entry choice, i.e. the choice between traditional market entry forms and online market entry. Yet, the stage nature of this perspective would require us to extend this thought experiment even further, i.e. to apply the thinking to later stages of the internationalization process. This is beyond the scope of this paper and in fact, we deem the OLI framework is better suited to explain the initial online-offline risk trade-off mechanism for the following two reasons: (a) it offers a wider range of dimensions to explain entry mode decisions (commitment) than experience (market knowledge) and risk perceptions, and (b) it is only concerned with the initial entry mode choice and how it affects firm performance. To this end, by adopting the OLI we offer a focused perspective of the online-offline risk trade-off that is concerned with the initial market entry decision and not concerned with the internationalization "life cycle" offered in the Uppsala model.

Regarding the OLI framework, we also emphasize that although on a theoretical level large multinational firms may also opt for online internationalization, due to their complexity, governance structure, and power inherent to their size, they are expected to employ ICT as a communication, coordination, and monitoring tool (Rangan \& Sengul, 2009) rather than as an alternative to physical presence. In the following, we will complement the work of Nakos and Brouthers (2002) and extend it to the online context.

\subsection{Ownership advantages}

Ownership advantages can be regarded as firm-specific competitive advantages in the form of income-generating tangible and intangible assets (Dunning, 2001; Dunning \& Wymbs, 2001). Firm-specific e-commerce assets, e-commerce experience (Dunning \& Wymbs, 2001), the firm's ability to differentiate as well as its size (Agarwal \& Ramaswami, 1992; Brouthers et al., 1996; Dunning, 1993) have all been identified as factors that provide ownership advantages and influence choice of market entry.

As observed by Prasad, Ramamurthy, and Naidu (2001) empirical findings are mixed regarding the direct effect of firm size on export behavior and performance. This seems to be similar in the online context. Thong (1999) tested the relationship between organizational characteristics such as business size and employees' information systems (IS) knowledge and the likelihood and extent of IS adoption respectively. Both relationships demonstrated significant positive results. Moini and Tesar (2005) examined the impact of the Internet on small manufacturing firms' exporting behavior. However, they did not find a significant relationship between firm size and Internet use for internationalization purposes. On the other hand, Morgan-Thomas and Bridgewater's (2004) regression results showed that the odds of online export success decrease with

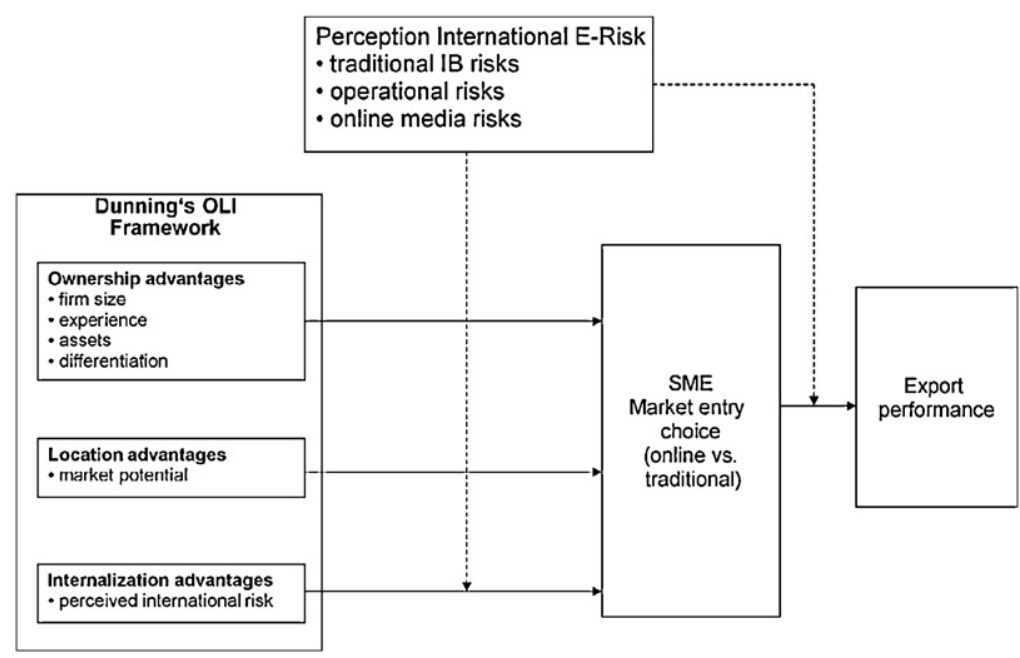

Fig. 1. A framework of the role of international e-risks in SME choice of market entry and performance outcomes. 
firm size. Furthermore, Arbore and Ordanini (2006) empirically investigated the broadband divide among SMEs and concluded that firms with less than about fifty employees may not be able to afford the internalization of all ICT activities (Arbore \& Ordanini, 2006). Notwithstanding these controversial empirical results, a pattern seems to emerge. Despite the existing "consensus in the international business literature that larger companies possess more financial and human resources" (Katsikeas, Deng, \& Wartzel, 1997, p.56) facilitating their internationalization, smaller firms have been found to compensate for their lack of resources by combining advanced technologies with deep-niche strategies (Kohn, 1997; Shrader et al., 2000) as well as by relying on non-equity modes of entry (Contractor, 1984). Firm size may thus constitute a competitive advantage in terms of organizational flexibility (Moini \& Tesar, 2005). However, even among SMEs there may be a substantial difference in resource availability depending on which sub-category a firm belongs to, i.e. micro, small or medium (European Commission, 2003; Nakos \& Brouthers, 2002). This uneven resource distribution is not only relevant in the physical environment when it comes to equity versus non-equity entry mode decisions (Osborne, 1996), but also has implications in the online context. SMEs need to be able to invest in sophisticated e-commerce technology in order to successfully engage in online internationalization (Morgan-Thomas \& Bridgewater, 2004; Stray, Bridgewater, \& Murray, 2001). Although, there is empirical evidence that ICT outsourcing strategies tend to alleviate size restrictions, allowing smaller firms with less than 50 employees (hitherto mid-sized SMEs) to participate in cyberspace (Arbore \& Ordanini, 2006), we propose that:

P1a. Mid-sized SMEs are more likely to prefer online market entry than micro or small enterprises.

E-commerce assets can be generally defined as investments in IT infrastructure and human resources which enable firms "to develop e-commerce functions that could serve as a source of competitive advantage" (Karavdic \& Gregory, 2005, p. 90). Commitment of resources to the development and implementation of e-commerce assets has been found to have a positive significant impact on online internationalization success (Morgan-Thomas \& Bridgewater, 2004). This underscores Dunning and Wymbs' (2001) view that e-commerce advantages stem from property rights based on technology, standards, or preferred customer interfaces. Furthermore, a survey among 340 Australian SME export ventures provides evidence that e-commerce assets positively and significantly impact firms' promotion adaptation, communication efficiency, distribution support, distribution efficiency, and price competitiveness (Jean et al., 2008). An increased investment in ICT infrastructure and in employee skills also proved to enhance management commitment to e-commerce (Gregory et al., 2007). Thus it can be expected that SMEs which continuously invest in e-commerce assets in order to develop firm-specific competitive advantages, will favor online market entry when confronted with a choice over physical market entry strategy.

P1b. SMEs with firm-specific e-commerce assets are more likely to prefer online market entry

Research on the role of managerial experience in SMEs' equity entry mode decisions suggests that firms are more likely to engage in more committed modes of physical market entry when managers exhibit higher levels of international experience (Brouthers et al., 1996; Shrader et al., 2000). However, in the online context this translates into a slightly paradoxical situation. While managers may opt for online internationalization instead of traditional market entry modes, to compensate for their lack of international experience (Bennett, 1997), empirical findings on success results differ significantly. Vahlne and Johanson (2002) found that many of the Internet companies they had investigated at an earlier point in time became subject to business failure because they underestimated the importance of international experience in cross-border ecommerce. Morgan-Thomas and Bridgewater (2004), on the other hand, suggest that SMEs with less exporting experience tend to be more successful as they will potentially be more committed to online internationalization. Conversely, the relevance of e-commerce experience as an ownership advantage (Dunning \& Wymbs, 2001) and driver for online internationalization seems to be relatively well documented in the literature (e.g. Berry \& Brock, 2004; Morgan-Thomas \& Bridgewater, 2004; Stockdale \& Standing, 2006; Thong, 1999). Consequently, a certain level of international experience seems to be a necessary, yet not a sufficient condition, for online market entry choice. Thus, from the above argument, a positive relationship between an SME's e-commerce experience level and its online market entry decision can be derived under the assumption that firms possess an appropriate level of international business experience.

P1c. SMEs with higher levels of e-commerce experience are more likely to prefer online market entry than those with less Internet experience.

According to Porter (2001), the Internet provides specific advantages in terms of information availability, ease of communication, geographic market expansion, and low entry barriers. These factors contribute to "destructive price competition" by increasing competitive pressure and reducing variable costs (Porter, 2001, p. 66). For SMEs it is rather difficult to exploit economies of scale, consequently they are usually less likely to be successful on cost leadership strategies (Miller \& Toulouse, 1986). For this reason, the design and implementation of a unique differentiation strategy constitutes a valuable ownership advantage for e-companies. The existence of so-called "shopbots" (Rodríguez-Ardura, Meseguer-Artola, \& Vilaseca-Requena, 2008) providing consumers with a tool for fast and easy price comparison, further underscores the value of such an advantage. Karagozoglu and Lindell (2004) found empirical evidence that SMEs are more likely to succeed in highly differentiated product markets than in commodity or quasi commodity markets (Karagozoglu \& Lindell, 2004). This is also in line with Rodríguez-Ardura et al. (2008) results, confirming that there is a positive and significant relationship between differentiation strategies, providing consumers with greater value and firms' propensity to engage in e-commerce. 
Furthermore Kim, Song, and Koo (2008) found evidence that in the online context, innovative differentiation strategies substantially contribute to firms' performance success. Thus, we propose that:

P1d. SMEs with innovative differentiation strategies are more likely to prefer online market entry.

\subsection{Location advantages}

Location advantages are concerned with country-specific characteristics of the target market which enable firms to leverage their ownership advantages (Dunning, 2001). In the online context this translates into advantages stemming from a target country's online market potential (Dunning \& Wymbs, 2001).

The e-commerce infrastructure in the host country needs to be well-developed with "easy and affordable access to $e$ commerce networks" (Karavdic \& Gregory, 2005, p. 92) to facilitate an efficient expansion of e-companies. When it comes to physical distribution of goods, the existence and state of a country's physical infrastructures such as roads, rail, air, and water networks, maintain their traditional relevance. Also, the distribution of intangible and digital products is affected by a country's poor infrastructure in a traditional sense where factors such as electricity are concerned (Brouthers, 1995). SMEs also need to consider compatibility issues such as differences in bandwidth across countries affecting the speed of information flows (Javalgi, Wickramasinghe, Scherer, \& Sharma, 2005), in telecommunications infrastructure, e.g. phone lines, fiber trunks, etc. (Javalgi et al., 2005), in the Internet access method used by customers, such as computers, mobile phones, TV sets etc. (Guillen, 2002), in the cost of Internet use (Guillen, 2002; Javalgi et al., 2005) and in the number of Internet hosts (Javalgi et al., 2005). Apart from infrastructure issues, online market potential also includes the demand for ecommerce in the host country. In cultures where buying at a distance is not in line with tradition, it can be expected that demand for e-commerce will be rather low (Harrison-Walker, 2002). Favorable government policy (Dunning \& Wymbs, 2001 ) is also an important aspect of online market potential. While the Internet is reducing certain traditional trade barriers (Hamill, 1997; Porter, 2001), the inter-country regulatory competition, inter alia, to set ICT standards (Winn, 2007) may still lead to government measures affecting the flow of products and/or information (Braga, 2005; Frynas, 2002; Kobrin, 2001). It appears that countries tend to regulate e-commerce in a similar fashion to the way in which they regulate other domestic issues (Winn, 2007). Consequently, less democratic countries may take action of a protectionist nature which might impair foreign e-companies' business expansion (Andonova, 2006; Braga, 2005; Harrison-Walker, 2002). From the above, we derive the following proposition:

P2. SMEs which experience a high degree of online market potential in a given country are more likely to prefer online market entry modes.

\subsection{Internalization advantages}

Internalization advantages are mainly concerned with reducing transaction and coordination related costs in the target country (Dunning, 1993, 2001). In the literature internalization advantages have been conceptualized by a number of researchers as contractual risks consisting of: (1) contract compilation and enforcement costs; (2) proprietary know-how dissemination risk; and (3) quality controlling and monitoring costs (Agarwal \& Ramaswami, 1992; Brouthers, Brouthers, \& Werner, 1999). Other studies have focused on a more elaborate catalogue of international risks including externally oriented dimensions (Ahmed, Mohamad, Tan, \& Johnson, 2002; Brouthers, 1995; Shrader et al., 2000). Although these studies investigate the inter-relationship between traditional international risk perceptions and entry mode selection, there is a certain amount of incongruence in the attribution of some risk constructs to specific OLI dimensions, particularly to location versus internalization advantages (see e.g. Brouthers, 1995; Nakos \& Brouthers, 2002). In this paper, following the integrative approach outlined in Fig. 1, we attribute risk perception related entry mode choice to the internalization-specific component of the OLI framework. There is empirical evidence for the existence of international risk trade-offs between perceived country risk, resource commitment and market revenue exposure in the international business literature (Ahmed et al., 2002; Miller, 1992; Shrader et al., 2000). Previous research has also documented that high levels of traditional international risk perception in a target market may lead to less committed market entry modes in terms of resources and control (Brouthers, 1995; Nakos \& Brouthers, 2002). Following real options theory, ICT seems to offer a low-resource commitment and high-control alternative to physical market entry when it comes to strategic decision making under high risk perceptions (Dunning \& Wymbs, 2001). Thus, the following proposition is put forward:

P3. SMEs are more likely to prefer online market entry when total perceived international risk is high than when total perceived international risk is low

\subsection{Perceived international e-risk}

Perception is a learned mental process used to reduce the complexity of information about the environment. Market entry decisions are based on "perceptions of the environment, [and] not on environmental reality" (Johnston \& Wright, 2004, p. 
235). Following on from Proposition 3, high perceived traditional international risk with respect to a target market may lead to online market entry, as this allows the firm to retain control over critical operations (Brouthers, 1995) or to exploit tradeoffs between international risk factors (Miller, 1992; Shrader et al., 2000). Thus, it may appear that online market entry has the potential to counter-balance the trade-off between risk, resource commitment and control. Yet, as delineated in the international e-risk framework section (see Section 2), online market entry exhibits its own set of risks. Consequently, the perception of international e-risks entails a different kind of managerial trade-off decision. In this scenario, traditional international business risks are traded off against international e-risks. We term this the "online-offline risk trade-off".

P4. High levels of perceived e-risk have a negative moderating effect on the perceived traditional international risk-online market entry selection relationship.

The classification of e-risks into traditional IB, operational and online media risks is important as risks belonging to the respective categories may be perceived differently by managers. It can be expected that traditional IB risks in the online context will be deemed less relevant by managers than operational or online media risks. As discussed in Section 2 this is due to the varying ease in which the respective categories can be identified. Despite the differences in perceived relevance, they can be still expected to have a negative moderating effect on online internationalization decisions. Thus, we propose that:

P4a. High perceptions of traditional IB e-risk have a negative moderating effect on the perceived traditional international risk-online market entry selection relationship.

P4b. High perceptions of business e-risk have a negative moderating effect on the perceived traditional international riskonline market entry selection relationship.

P4c. High perceptions of online media risk have a negative moderating effect on the perceived traditional risk-online market entry selection relationship.

\subsection{Export performance}

The OLI framework builds on a number of economic and behavioral theories including transaction cost economic (TCE) theory (Dunning, 2001). Brouthers and Nakos (2004) investigated SME entry mode choice from a TCE perspective. They found support for small firms exhibiting a significantly better performance when selecting entry modes suggested by TCE, as opposed to other modes of entry (Brouthers \& Nakos, 2004). In line with this, it can be expected that firms choosing an OLI-predicted entry mode strategy will demonstrate a better export performance than firms which opt for a different alternative. Thus it can be expected that:

P5. There is a positive relationship between OLI-predicted entry mode selection and export performance.

In addition to their moderating function on online market entry selection, e-risk perceptions may also play an important role after the online entry decision has actually been made. The frequent occurrence of online media risks such as security breaches, reliability problems (e.g. download delays, limitations of the interface etc.), and other risks causing customer damage or dissatisfaction, have been found to negatively affect company performance (Reeves, 2000; Rose, Khoo, \& Straub, 1999). Traditional IB and operational risks (e.g. transfer, legal or industry structure) exert an indirect effect as it is more difficult for companies to avert them. Still, their existence is believed to have a negative effect on company profitability (Braga, 2005; Porter, 2001; Reeves, 2000). Consequently, when the occurrence of online risks is perceived to be equally high after an online market entry strategy has taken place, it can be expected that an SME's export sales and export performance as a whole will be affected (Acedo \& Florin, 2007; Andrijcic \& Horowitz, 2006; Bromiley, 1991). Based on this argument the following proposition can be derived:

P6. High perceptions of international e-risk have a moderating effect on the relationship between OLI-predicted entry mode selection and export performance.

\section{Conclusions}

Combining the extant international business, risk management and e-commerce literatures, this paper aimed at proposing a multidimensional international e-risk framework and integrating it into a larger conceptual framework to explain SMEs' online market entry decisions. For this purpose we chose Dunning's (2001) OLI framework as it has already demonstrated considerable explanatory value for SMEs' traditional internationalization decisions in the physical domain. As our main focus was on the nature of international e-risks and how perceptions of these may influence online internationalization decisions we did not aim to develop a completely new model. Instead, we adopted and extended the OLI framework and built on existing work on the explanation of small firm internationalization decisions by Nakos and Brouthers (2002). The fact that the OLI framework has been already extensively researched in international business simultaneously represents an advantage and a limitation. As its components are widely known it represents a comprehensive context for the integration of the international e-risk dimensions. Thus it can be deemed as a valuable first 
step in the development of a new and potentially more comprehensive model which future research may consider. Future work may also test the relationship of constructs in a comprehensive nomological network. Overall, it is suggested that firms opting for an OLI-predicted entry mode will exhibit a better export performance than firms for which the OLI framework foresees a different internationalization strategy. The international e-risk framework in this article not only attempts to integrate traditional international business risks into emerging e-commerce risk constructs, but it is also suggested to have a moderating effect on managerial decisions for online entry as well as on the relationship between OLI-predicted entry form and export performance. The framework also allows for a comparison of the effects of traditional international risk perceptions (Brouthers, 1995) and international e-risk perceptions on entry mode decisions which we term the "online-offline risk trade-off". While traditional international risks are a constituent of the OLI framework and have a direct influence on managerial decisions, international e-risks (especially traditional IB risks) are suggested as acting as moderators partly due to their unexplored nature. We have indicated that owner-managers may perceive operational and online media risks more relevant for online internationalization than traditional IB risks. Future work is required to operationalize and empirically test the proposed conceptual framework, but also to examine how international e-risk perceptions change with increased e-commerce experience over time. Furthermore, the proposed framework only addresses the initial market entry mode decision and does not consider changes throughout later stages of a firm's internationalization process. To this end, future research may wish to examine the entire decision sequence and apply behavioral models of firm internationalization such as the Uppsala model.

Despite its conceptual nature the present paper points to implications of high managerial relevance. The latency of certain risk dimensions and the considerable time-lag between their activation and their visible effects calls for an integrated risk management. Examples of poor risk assessment consequences include overly optimistic numbers in an e-company's business plan potentially resulting in negative long-term effects on its financing. Furthermore, ignoring or under-estimating certain risks can result in faulty contingency plans leading to business discontinuity, major financial losses, or complete business failure. Thus, awareness of the potential risks in online internationalization represents the first step in effective online risk management.

\section{Appendix A}

See Table 1.

Table 1

International e-risks framework-dimensions identified in the literature.

\begin{tabular}{|c|c|c|c|c|}
\hline Dimensions & $\begin{array}{l}\text { Relevant element } \\
\text { affected by ICT }\end{array}$ & $\begin{array}{l}\text { How has ICT transformed } \\
\text { the nature of the selected } \\
\text { risk element }\end{array}$ & Implications & Source \\
\hline \multicolumn{5}{|l|}{ Traditional IB risks } \\
\hline Ownership risk & $\begin{array}{l}\text { Ownership/control of } \\
\text { company assets }\end{array}$ & $\begin{array}{l}\text { Possibility of no physical } \\
\text { presence in a traditional } \\
\text { sense, e.g., in form of a } \\
\text { JV or WOS }\end{array}$ & $\begin{array}{l}\text { Physical manifestations of } \\
\text { an e-business are still } \\
\text { subject to control and/or } \\
\text { ownership limitations e.g. } \\
\text { Internet backbone, server } \\
\text { building, website etc. }\end{array}$ & $\begin{array}{l}\text { Ahmed et al. (2002), } \\
\text { Brouthers (1995), } \\
\text { Frynas (2002) }\end{array}$ \\
\hline \multirow[t]{2}{*}{$\begin{array}{l}\text { Marketing } \\
\quad \text { infrastructure }\end{array}$} & $\begin{array}{l}\text { Advertising, selling, } \\
\text { distributing by using } \\
\text { specific infrastructure }\end{array}$ & $\begin{array}{l}\text { In the case of pure online } \\
\text { companies with intangible- } \\
\text { dominant products the } \\
\text { main advertising, selling } \\
\text { and distribution } \\
\text { infrastructure is the } \\
\text { Internet worldwide }\end{array}$ & $\begin{array}{l}\text { There are differences } \\
\text { across countries regarding } \\
\text { consumer and/or } \\
\text { government reactions to } \\
\text { specific advertising } \\
\text { forms e.g. banner ad }\end{array}$ & $\begin{array}{l}\text { Ahmed et al. (2002), } \\
\text { Brouthers (1995), } \\
\text { Guillen (2002), } \\
\text { Hoy and Lwin (2008), } \\
\text { Javalgi et al. (2005) }\end{array}$ \\
\hline & $\begin{array}{l}\text { Availability of a s } \\
\text { tructured and } \\
\text { secured infrastructure }\end{array}$ & $\begin{array}{l}\text { Traditional physical } \\
\text { infrastructure elements } \\
\text { such as roads, railways, } \\
\text { shipping routes become } \\
\text { for pure online companies } \\
\text { with intangible products } \\
\text { obsolete }\end{array}$ & $\begin{array}{l}\text { A structured and secure } \\
\text { ICT infrastructure is } \\
\text { needed along with stable } \\
\text { power supply. } \\
\text { There may be differences } \\
\text { across countries in terms } \\
\text { of available access } \\
\text { methods, bandwidth etc. } \\
\text { E-companies with tangible } \\
\text { products still need to } \\
\text { rely on traditional } \\
\text { physical infrastructure }\end{array}$ & \\
\hline Consumer taste & $\begin{array}{l}\text { Variation in consumer } \\
\text { tastes across countries }\end{array}$ & $\begin{array}{l}\text { Potential to reach a large } \\
\text { number of customers on } \\
\text { a global scale }\end{array}$ & $\begin{array}{l}\text { Consumers may use } \\
\text { the firm's products in } \\
\text { different ways or not } \\
\text { use them at all across } \\
\text { countries }\end{array}$ & $\begin{array}{l}\text { Ahmed et al. (2002), } \\
\text { Brouthers (1995), } \\
\text { de la Torre and } \\
\text { Moxon (2001), } \\
\text { Miller (1992) }\end{array}$ \\
\hline
\end{tabular}


Table 1 (Continued)

\begin{tabular}{|c|c|c|c|c|}
\hline Dimensions & $\begin{array}{l}\text { Relevant element } \\
\text { affected by ICT }\end{array}$ & $\begin{array}{l}\text { How has ICT transformed } \\
\text { the nature of the selected } \\
\text { risk element }\end{array}$ & Implications & Source \\
\hline Market demand & $\begin{array}{l}\text { Current and future market } \\
\text { demand }\end{array}$ & $\begin{array}{l}\text { Internet allows for pooling } \\
\text { market demand from all } \\
\text { over the world }\end{array}$ & $\begin{array}{l}\text { Difficulties to assess } \\
\text { the amplitude of current } \\
\text { and future demand }\end{array}$ & $\begin{array}{l}\text { Ahmed et al. (2002), } \\
\text { Brouthers (1995), } \\
\text { Root (1987) }\end{array}$ \\
\hline Political & Political stability & $\begin{array}{l}\text { As in the case of ownership } \\
\text { risk ICT offers the possibility } \\
\text { of online instead of physical } \\
\text { market presence }\end{array}$ & $\begin{array}{l}\text { In the event of a war or } \\
\text { other destructive turmoil, } \\
\text { ICT infrastructure can } \\
\text { be damaged } \\
\text { Government can block } \\
\text { access to foreign websites } \\
\text { Power cuts, depreciation } \\
\text { of currency, illiquidity } \\
\text { of consumers, drastic } \\
\text { demand cutbacks }\end{array}$ & $\begin{array}{l}\text { Bannister and Bawcutt } \\
\text { (1981), Brouthers (1995), } \\
\text { Davies (1981), Frynas } \\
\text { (2002), Kobrin (1979), } \\
\text { Lynne (2000), } \\
\text { Mascarenhas and } \\
\text { Atherton (1983), } \\
\text { Miller (1992), Nagurney } \\
\text { and Matsypura (2005), } \\
\text { Oetzel (2005), Root (1987) }\end{array}$ \\
\hline Currency & $\begin{array}{l}\text { Foreign exchange rates, } \\
\text { balance-sheet exposure, } \\
\text { inflation, interest rates }\end{array}$ & $\begin{array}{l}\text { Online internationalization } \\
\text { makes it possible to have } \\
\text { most of the balance-sheet } \\
\text { assets in the home country. } \\
\text { New Technologies allow for } \\
\text { the collapsing of purchasing } \\
\text { sequences }\end{array}$ & $\begin{array}{l}\text { Differences in preferred } \\
\text { payment methods } \\
\text { across countries }\end{array}$ & $\begin{array}{l}\text { Elliott and Speck (2005), } \\
\text { Guillen (2002), } \\
\text { Harrison-Walker (2002), } \\
\text { Lehdonvirta (2009), } \\
\text { Mathur and Hanagan } \\
\text { (1981), Nagurney and } \\
\text { Matsypura (2005), } \\
\text { Scott (2004), Soenen (1979) }\end{array}$ \\
\hline Transfer & $\begin{array}{l}\text { Restrictions of goods, } \\
\text { services, and/or capital } \\
\text { flows across borders }\end{array}$ & $\begin{array}{l}\text { Internet reduces a number } \\
\text { of trade barriers }\end{array}$ & $\begin{array}{l}\text { Inter-country regulatory } \\
\text { competition to set ICT } \\
\text { standards still affects the } \\
\text { undisturbed flow of } \\
\text { products and/or information }\end{array}$ & $\begin{array}{l}\text { Ahmed et al. (2002), } \\
\text { Braga (2005), Brouthers } \\
\text { (1995), Frynas (2002), } \\
\text { Kobrin (2001), Lips } \\
\text { and Koops (2005), } \\
\text { Miller (1992), Root } \\
\text { (1987), Winn (2007) }\end{array}$ \\
\hline Legal & $\begin{array}{l}\text { Complying with local, } \\
\text { state, federal or } \\
\text { foreign law regulations }\end{array}$ & $\begin{array}{l}\text { Increasing participation of } \\
\text { states in e-governance } \\
\text { facilitates the access to } \\
\text { legal information and the } \\
\text { participation in legal } \\
\text { processes }\end{array}$ & $\begin{array}{l}\text { E-companies targeting } \\
\text { consumers on a global scale } \\
\text { lose control over compliance } \\
\text { with local, state, and/or } \\
\text { federal laws in foreign } \\
\text { markets due to reduced } \\
\text { transparency of the range } \\
\text { of foreign markets entered }\end{array}$ & $\begin{array}{l}\text { Bannister and Bawcutt } \\
\text { (1981), Burk (1996), } \\
\text { Grzebiela (2002), } \\
\text { Kobrin (2001), } \\
\text { Rosenkranz and } \\
\text { Missler-Behr (2005), } \\
\text { Scott (2004), } \\
\text { Wat et al. (2005) }\end{array}$ \\
\hline $\begin{array}{r}\text { Management } \\
\text { experience }\end{array}$ & $\begin{array}{l}\text { International } \\
\text { experience }\end{array}$ & $\begin{array}{l}\text { Access to a vast pool of } \\
\text { codified knowledge }\end{array}$ & $\begin{array}{l}\text { Especially in the domain } \\
\text { of online } \\
\text { internationalization there } \\
\text { is not much practical } \\
\text { information available }\end{array}$ & $\begin{array}{l}\text { Berry and Brock (2004), } \\
\text { Brouthers (1995), } \\
\text { Figureira-de-Lemos et al. } \\
\text { (2010), Moini and } \\
\text { Tesar (2005), Petersen, }\end{array}$ \\
\hline & ICT experience & $\begin{array}{l}\text { Relative affordability of ICT } \\
\text { infrastructure as opposed to } \\
\text { the establishment of foreign } \\
\text { subsidiaries }\end{array}$ & $\begin{array}{l}\text { Lack of adequate } \\
\text { international experience } \\
\text { hampers strategic } \\
\text { decision making leading } \\
\text { to business failure } \\
\text { Lack of ICT experience } \\
\text { and know-how hinders the } \\
\text { deployment of online } \\
\text { opportunities to their } \\
\text { full potential }\end{array}$ & $\begin{array}{l}\text { Welch, and Liesch (2002), } \\
\text { Scott (2004), Vahlne } \\
\text { and Johanson (2002) }\end{array}$ \\
\hline Cultural difference & $\begin{array}{l}\text { Cultural differences } \\
\text { across markets }\end{array}$ & $\begin{array}{l}\text { Global reach of customers } \\
\text { with differing cultural } \\
\text { backgrounds }\end{array}$ & $\begin{array}{l}\text { Omitting to take cultural } \\
\text { differences into account } \\
\text { may alienate consumers } \\
\text { from certain cultures }\end{array}$ & $\begin{array}{l}\text { Brouthers (1995), } \\
\text { Lim, Leung, Sia, and } \\
\text { Lee (2004), Reeves } \\
\text { (2000), Scott (2004), } \\
\text { Wat et al. (2005), } \\
\text { Yamin and } \\
\text { Sinkovics (2006) }\end{array}$ \\
\hline
\end{tabular}


Table 1 (Continued)

\begin{tabular}{|c|c|c|c|c|}
\hline Dimensions & $\begin{array}{l}\text { Relevant element } \\
\text { affected by ICT }\end{array}$ & $\begin{array}{l}\text { How has ICT transformed } \\
\text { the nature of the selected } \\
\text { risk element }\end{array}$ & Implications & Source \\
\hline Industry structure risk & Market concentration & $\begin{array}{l}\text { New Technologies lower } \\
\text { market entry and exit } \\
\text { barriers }\end{array}$ & $\begin{array}{l}\text { Difficulties in assessing } \\
\text { the real level of } \\
\text { competition }\end{array}$ & $\begin{array}{l}\text { Ahmed et al. (2002), } \\
\text { Brouthers (1995), } \\
\text { Porter (2001), } \\
\text { Rosenkranz and } \\
\text { Missler-Behr (2005) }\end{array}$ \\
\hline \multicolumn{5}{|l|}{ Operational risks } \\
\hline Credit & $\begin{array}{l}\text { Risk of payment delays } \\
\text { and/or non-payment }\end{array}$ & $\begin{array}{l}\text { Dilution of sequencing in } \\
\text { the buying process }\end{array}$ & $\begin{array}{l}\text { Credit card fraud or } \\
\text { other fraudulent } \\
\text { behaviors leading to } \\
\text { non-payment }\end{array}$ & $\begin{array}{l}\text { Brouthers (1995), } \\
\text { Miller (1992), } \\
\text { Rosenkranz and } \\
\text { Missler-Behr (2005) }\end{array}$ \\
\hline Dependency & $\begin{array}{l}\text { Changing business } \\
\text { relationship structures }\end{array}$ & $\begin{array}{l}\text { Disintermediation, } \\
\text { re-intermediation, } \\
\text { outsourcing }\end{array}$ & $\begin{array}{l}\text { Over-dependent } \\
\text { relationships on third } \\
\text { party service providers } \\
\text { such as Application } \\
\text { service Providers (ASP) } \\
\text { Unreliable service from } \\
\text { the outsourcing partner } \\
\text { leading to business } \\
\text { discontinuity, data } \\
\text { loss etc. }\end{array}$ & $\begin{array}{l}\text { Currie (2003), } \\
\text { Scott (2004), Willcocks, } \\
\text { Lacity, and Kern (1999) }\end{array}$ \\
\hline Intellectual property & $\begin{array}{l}\text { Trade secrets, patents, } \\
\text { trademarks, copyrights etc. }\end{array}$ & $\begin{array}{l}\text { Global online collaboration } \\
\text { on R\&D projects, facilitated } \\
\text { information search, } \\
\text { knowledge transfer etc. }\end{array}$ & $\begin{array}{l}\text { Increased vulnerability } \\
\text { to intellectual property } \\
\text { theft } \\
\text { Long-term effect } \\
\text { Major financial losses }\end{array}$ & $\begin{array}{l}\text { Andrijcic and } \\
\text { Horowitz (2006), } \\
\text { Braga (2005), } \\
\text { Frynas (2002), } \\
\text { Penz (2007), } \\
\text { Scott (2004) }\end{array}$ \\
\hline Reputation & $\begin{array}{l}\text { Reputation as valuable } \\
\text { intangible company asset }\end{array}$ & Increased visibility & $\begin{array}{l}\text { Zero tolerance of } \\
\text { consumers } \\
\text { Blogs, product } \\
\text { comparison platforms, } \\
\text { discussion boards } \\
\text { contribute to the } \\
\text { real time distribution } \\
\text { of consumer opinion } \\
\text { Lacking physical cues } \\
\text { consumers use peer } \\
\text { ratings as reference } \\
\text { points for buying decisions }\end{array}$ & $\begin{array}{l}\text { Ba and Pavlou (2002), } \\
\text { Beck and Franke (2008), } \\
\text { Grzebiela (2002), } \\
\text { Lee, Kauffman, } \\
\text { and Bergen (2009), } \\
\text { Lynne (2000), } \\
\text { Pennathur (2001), } \\
\text { Qureshi et al. (2009), } \\
\text { Reeves (2000), } \\
\text { Scott (2004) }\end{array}$ \\
\hline Profitability & Profits & $\begin{array}{l}\text { Increased market } \\
\text { penetration }\end{array}$ & $\begin{array}{l}\text { Product comparison } \\
\text { platforms, also called } \\
\text { "shopbots", are forcing } \\
\text { the company into } \\
\text { severe price competition }\end{array}$ & $\begin{array}{l}\text { Magnússon (1963), } \\
\text { Rasheed (2009), } \\
\text { Rodríguez- } \\
\text { Ardura et al. (2008), } \\
\text { Scott (2004) }\end{array}$ \\
\hline \multirow[t]{2}{*}{ Reliability } & Technology & $\begin{array}{l}\text { New opportunities, new } \\
\text { solutions, increased } \\
\text { efficiency }\end{array}$ & $\begin{array}{l}\text { System failure leading } \\
\text { to business discontinuity }\end{array}$ & $\begin{array}{l}\text { Butler and Gray (2006), } \\
\text { Moscove (2001), } \\
\text { Reeves (2000), } \\
\text { Scott (2004) }\end{array}$ \\
\hline & & & $\begin{array}{l}\text { Rapid technological } \\
\text { change requires } \\
\text { continuous upgrade }\end{array}$ & \\
\hline \multirow[t]{2}{*}{ Logistics } & Logistical dimensions & $\begin{array}{l}\text { More efficient inventory } \\
\text { systems }\end{array}$ & $\begin{array}{l}\text { Challenges in dealing } \\
\text { with the return of } \\
\text { digital goods, or with } \\
\text { the return of physical } \\
\text { goods over long distances }\end{array}$ & $\begin{array}{l}\text { Biederman (1999), } \\
\text { Delfmann, Albers, } \\
\text { and Gehring (2002), } \\
\text { Rasheed (2009), } \\
\text { Reeves (2000), } \\
\text { Scott (2004), } \\
\text { Wresch (2003) }\end{array}$ \\
\hline & & $\begin{array}{l}\text { Automatization of } \\
\text { administrative processes }\end{array}$ & $\begin{array}{l}\text { Correct quotation of } \\
\text { delivery costs } \\
\text { Timely delivery } \\
\text { Difficulties resulting from } \\
\text { deferring technological } \\
\text { standards }\end{array}$ & \\
\hline Competitive & Competitiveness & Facilitated market entry & $\begin{array}{l}\text { Channel cannibalization } \\
\text { versus beneficial } \\
\text { complementary impact } \\
\text { of offline presence }\end{array}$ & $\begin{array}{l}\text { Lynne (2000), } \\
\text { Porter (2001), Scott } \\
\text { (2004), Vitale (1986) }\end{array}$ \\
\hline
\end{tabular}


Table 1 (Continued)

\begin{tabular}{|c|c|c|c|c|}
\hline Dimensions & $\begin{array}{l}\text { Relevant element } \\
\text { affected by ICT }\end{array}$ & $\begin{array}{l}\text { How has ICT transformed } \\
\text { the nature of the selected } \\
\text { risk element }\end{array}$ & Implications & Source \\
\hline Strategy & $\begin{array}{l}\text { Strategy design and/ } \\
\text { or implementation }\end{array}$ & $\begin{array}{l}\text { Access to information } \\
\text { facilitating strategic } \\
\text { decision making }\end{array}$ & $\begin{array}{l}\text { Low switching costs for } \\
\text { customers negating the } \\
\text { positive effects of network } \\
\text { externalities } \\
\text { Potentially incorrect } \\
\text { choice of online product } \\
\text { offerings } \\
\text { Strategy can be a source } \\
\text { of risk } \\
\text { - When it changes the } \\
\text { basis of competition } \\
\text { - When it disturbs the } \\
\text { balance in innovator- } \\
\text { customer or innovator- } \\
\text { supplier power } \\
\text { - When it is badly timed or } \\
\text { - When it attracts } \\
\text { new entrants }\end{array}$ & $\begin{array}{l}\text { Bannister and Bawcutt } \\
\text { (1981), Guillen (2002), } \\
\text { Karavdic and Gregory } \\
\text { (2005), Porter (2001), } \\
\text { Quelch and Klein (1996), } \\
\text { Scott (2004), Vitale (1986) }\end{array}$ \\
\hline \multicolumn{5}{|l|}{ Online media risks } \\
\hline Identity & Company identity & $\mathrm{N} / \mathrm{A}$ & $\begin{array}{l}\text { Being victim of } \\
\text { identity theft }\end{array}$ & $\begin{array}{l}\text { Grzebiela (2002), } \\
\text { Kobrin (2001), } \\
\text { Scott (2004) }\end{array}$ \\
\hline Identification & $\begin{array}{l}\text { Business partner and/ } \\
\text { or consumer identity }\end{array}$ & $\mathrm{N} / \mathrm{A}$ & $\begin{array}{l}\text { Misinformation by } \\
\text { prospective partners } \\
\text { Difficulty in determining } \\
\text { partner location (false } \\
\text { IP addresses) }\end{array}$ & $\begin{array}{l}\text { Kobrin (2001), Scott } \\
\text { (2004), Winn (2007) }\end{array}$ \\
\hline Privacy & Information security & $\mathrm{N} / \mathrm{A}$ & $\begin{array}{l}\text { Confidential information } \\
\text { and data theft }\end{array}$ & $\begin{array}{l}\text { Reeves (2000), } \\
\text { Scott (2004) }\end{array}$ \\
\hline Security & Web site security & $\mathrm{N} / \mathrm{A}$ & $\begin{array}{l}\text { Hacker attacks, viruses, } \\
\text { worms, etc. }\end{array}$ & $\begin{array}{l}\text { Lynne (2000), Scott } \\
\text { (2004), Winn (2007) }\end{array}$ \\
\hline Physical security & Hardware components & $\mathrm{N} / \mathrm{A}$ & $\begin{array}{l}\text { Business discontinuity, } \\
\text { data loss due to physical } \\
\text { destruction of company } \\
\text { server }\end{array}$ & $\begin{array}{l}\text { Bannister and Bawcutt } \\
\text { (1981), Lynne (2000), } \\
\text { Miller (1992), } \\
\text { Wat et al. (2005) }\end{array}$ \\
\hline
\end{tabular}

\section{Appendix B}

\section{Comments regarding risk and uncertainty}

Despite sporadic attempts to develop a risk framework for cross-border activities (Brouthers, 1995; Miller, 1992), the international business literature still lacks a generally accepted definition of international risk (Ahmed et al., 2002; Miller, 1992). The concepts of risk and uncertainty have been used synonymously in past studies (e.g. Brouthers \& Nakos, 2004; Wu, Mahajan, \& Balasubramanian, 2003). This conceptual and definitional fuzziness is surprising, as Knight (1921) had already drawn a distinction between the two concepts on the basis of whether the probability of occurrence of an anticipated negative event is known or assessable. A possible explanation may be the relative novelty of risk management as a separate field (Elms, 1998). However, a differentiation between these two concepts is essential as they entail considerably different implications. While in the case of uncertainty, defensive measures are only possible to a very limited extent, risks are amenable to preventive managerial action. Risk can be thus said to be the manifestation of uncertainty. In this paper, international e-risk is defined as the assessable probability of limitations, restrictions, and/or losses facing firms conducting international business in cyberspace (Ahmed et al., 2002; Flowerday \& von Solms, 2005; Miller, 1992). While e-risks such as security abuse, identity theft, and privacy issues have attracted substantial attention in the literature (Scott, 2004), other less visible and sometimes longer-term threats especially in the online international marketplace remained, to a considerable extent, ignored. Bannister and Bawcutt (1981) categorized risks in the physical environment based on the criterion of insurability. Such a categorization of e-risks is very difficult as insurability in this domain is highly contingent on individual countries' legislation and on the existence of an adequate e-commerce insurance infrastructure (Grzebiela, 2002). Nevertheless, even though many of the e-risks cannot be insured and are only controllable to a limited extent, they can be managed, provided owner-managers are aware of their existence and the extent of their significance. 


\section{References}

Acedo, F. J., \& Florin, J. (2007). Understanding the risk perception of strategic opportunities: A tripartite model. Strategic Change, 16(3), 97-116.

Agarwal, S., \& Ramaswami, S. N. (1992). Choice of foreign market entry mode: Impact of ownership, location and internalization factors. Journal of International Business Studies, 23(1), 1-27.

Ahmed, Z. U., Mohamad, O., Tan, B., \& Johnson, J. P. (2002). International risk perceptions and mode of entry: A case study of Malaysian multinational firms. Journal of Business Research, 55(10), 805-813.

Andersson, U., Forsgren, M., \& Holm, U. (2001). Subsidiary embeddedness and competence development in MNCs-A multi-level analysis. Organization Studies, 22(6), 1013-1034.

Andonova, V. (2006). Mobile phones, the internet and the institutional environment. Telecommunications Policy, 30(1), 29-45.

Andrijcic, E., \& Horowitz, B. (2006). A macro-economic framework for evaluation of cyber security risks related to protection of intellectual property. Risk Analysis: An International Journal, 26(4), 907-923.

Arbore, A., \& Ordanini, A. (2006). Broadband divide among SMEs: The role of size, location and outsourcing strategies. International Small Business Journal, 24(1), 83-99.

Ba, S., \& Pavlou, P. A. (2002). Evidence of the effect of trust building technology in electronic markets: Price premiums and buyer behavior. MIS Quarterly, 26(3), $243-268$.

Bannister, J. E., \& Bawcutt, P. A. (1981). Practical risk management. London: Witherby \& Co Ltd.

Barney, J. B. (1991). Firm resources and sustained competitive advantage. Journal of Management, 17(1), 99-121.

Beck, R., \& Franke, J. (2008). Designing reputation and trust management systems. Journal of Electronic Commerce in Organizations, 6(4), 8-29.

Bell, J., Deans, K., Ibbotson, P., \& Sinkovics, R. R. (2001). Towards the 'internetalization' of international marketing education. Marketing Education Review, 11(3), 69-79.

Bennett, R. (1997). Export marketing and the internet: Experiences of web site use and perceptions of export barriers among UK businesses. International Marketing Review, 14(5), 324-344.

Berry, M. M. J., \& Brock, J.K.-U. (2004). Marketspace and the internationalisation process of the small firm. Journal of International Entrepreneurship, 2(3), 187216.

Biederman, D. (1999). Global e-headaches. Traffic World, 260(4), 21-121.

Braga, C. A. P. (2005). E-commerce regulation: New game, new rules? Quarterly Review of Economics and Finance, 45(2,3), 541-558.

Bromiley, P. (1991). Testing a causal model of corporate risk taking and performance. Academy of Management Journal, 34(1), 37-59.

Brouthers, K. D. (1995). The influence of international risk on entry mode strategy in the computer software industry. Management International Review, 35(1), $7-28$.

Brouthers, K. D., Brouthers, L. E., \& Werner, S. (1996). Dunning's eclectic theory and the smaller firm: The impact of ownership and locational advantages on the choice of entry-modes in the computer software industry. International Business Review, 5(4), 377-394.

Brouthers, K. D., \& Hennart, J.-F. (2007). Boundaries of the firm: Insights from international entry mode research. Journal of Management, 33(3), 395-425.

Brouthers, K. D., \& Nakos, G. D. (2004). SME entry mode choice and performance: A transaction cost perspective. Entrepreneurship Theory and Practice, 28(3), 229-247.

Brouthers, L. E., Brouthers, K. D., \& Werner, S. (1999). Is Dunning's eclectic framework descriptive or normative? Journal of International Business Studies, 30(4), 831-844.

Buckley, P. J. (1989). Foreign direct investment by small and medium-sized enterprises: The tehoretical background. Small Business Economics, 1(2), 89-100.

Burk, D. L. (1996). Federalism in cyberspace. Seaton Hall: School of Law, Seaton Hall University.

Butler, B. S., \& Gray, P. H. (2006). Reliability, mindfulness, and information systems. MIS Quarterly, 30(2), 211-224.

Ching, H. L., \& Ellis, P. (2004). Marketing in cyberpsace: What factors drive e-commerce adoption? Journal of Marketing Management, 20(3,4), 409-429.

Contractor, F. J. (1984). Choosing between direct investment and licensing: Theoretical considerations and empirical tests. Journal of International Business Studies, 15(3), 167-188.

Currie, W. L. (2003). A knowledge-based risk assessment framework for evaluating web-enabled application outsourcing projects. International Journal of Project Management, 21(3), 207-217.

Davies, W. (1981). Beyond the earthquake allegory: Managing political risk vulnerability. Management International Review, $21(3), 5-9$.

de la Torre, J., \& Moxon, R. W. (2001). Introduction to the symposium e-commerce and global business: The impact of the information and communication technology revolution on the conduct of international business. Journal of International Business Studies, 32(4), 617-639.

Delfmann, W., Albers, S., \& Gehring, M. (2002). The impact of electronic commerce on logistics service providers. International Journal of Physical Distribution E Logistics Management, 32(3/4), 203-222.

Dunning, J. H. (1980). Toward an electric theory of international production: Some empirical tests. Journal of International Business Studies, 11(1), 9-31.

Dunning, J. H. (1993). Multinational enterprises and the global economy. Wokingham, England: Addison-Wesley.

Dunning, J. H. (2001). The eclectic (oli) paradigm of international production: Past, present and future. International Journal of the Economics of Business, 8(2), $173-190$.

Dunning, J. H., \& Wymbs, C. (2001). The challenge of electronic markets for international business theory. International Journal of the Economics of Business, 8(2), $273-301$.

Elliott, M. T., \& Speck, P. S. (2005). Factors that affect attitude toward a retail web site. Journal of Marketing Theory and Practice, $13(1)$, 40-51.

Elms, D. (1998). Overview-Prudence, principles and practice. In D. Elms (Ed.), Owning the future: Integrated risk management in practice. CAE.

European Commission. (2003, June 20). Commission recommendation of 6 may 2003 concerning the definition of micro, small and medium-sized enterprises. <http:// europa.eu/eur-lex/pri/en/oj/dat/2003/1_124/1_12420030520en00360041.pdf > Retrieved June 20.06.08.

Figureira-de-Lemos, F., Johanson, J., \& Vahlne, J.-E. (2010). Risk management in the internationalization process of the firm: A note on the Uppsala model. Journal of World Business doi:10.1016/j.jwb.2010.1005.1008.

Flowerday, S., \& von Solms, R. (2005). Real-time information integrity = system integrity + data integrity + continuous assurances. Computers E Security, 24(8), $604-613$.

Forsgren, M. (2002). The concept of learning in the Uppsala internationalization process model: A critical review. International Business Review, 11(3), 257-277. Frynas, J. G. (2002). The limits of globalization-legal and political issues in e-commerce. Management Decision, 40(9), 871-880.

Gregory, G., Karavdic, M., \& Zou, S. (2007). The effects of e-commerce drivers on export marketing strategy. Journal of International Marketing, 15(2), 30-57. Grzebiela, T. (2002). Insurability of electronic commerce risks. Paper presented at the 35th Hawaii international conference on system sciences.

Guillen, M. F. (2002). What is the best global strategy for the internet? Business Horizons, 45(3), 39-46.

Hadjikhani, A., \& Johanson, J. (2002). Special issue on the internationalization process of the firm. International Business Review, 11(3), $253-255$.

Hamill, J. (1997). The internet and international marketing. International Marketing Review, 14(5), 300-323.

Hamill, J., \& Gregory, K. (1997). Internet marketing in the internationalisation of UK SMEs. Journal of Marketing Management, 13(1-3), 9-28.

Harrison-Walker, L. J. (2002). If you build it, will they come? Barriers to international e-marketing. Journal of Marketing Theory and Practice, 10(2), 12-21.

Hoy, M. G., \& Lwin, M. O. (2008). An international perspective of online disclosure presentation: A comparison of banner ad disclosures from United States, united kingdom, and Singapore web sites. Journal of Consumer Policy, 31(3), 327-347.

Javalgi, R. G, Wickramasinghe, N., Scherer, R. F., \& Sharma, S. K. (2005). An assessment and strategic guidelines for developing e-commerce in the Asia-Pacific region. International Journal of Management, 22(4), 523-531.

Jean, R.-J.B. (2007). The ambiguous relationship of ICT and organizational performance: A literature review. Critical Perspectives on International Business, 3(4), 306-321. 
Jean, R.-J.B., \& Sinkovics, R. R. (2010). Relationship learning and performance enhancement via advanced information technology: The case of Taiwanese dragon electronics firms. International Marketing Review, 27(2), 200-222.

Jean, R.-J.B., Sinkovics, R. R., \& Cavusgil, S. T. (2010). Enhancing international customer-supplier relationships through IT resources: A study of Taiwanese electronics suppliers. Journal of International Business Studies doi:2010.1057/jibs.2010.2014, advance online publication 4 March 2010.

Jean, R.-J.B., Sinkovics, R. R., \& Kim, D. (2008). Information technology and organizational performance within international business to business relationships: A review and an integrated conceptual framework. International Marketing Review, 25(5), 563-583.

Jean, R.-J.B., Sinkovics, R. R., \& Kim, D. (2010b). Drivers and performance outcomes of relationship learning for suppliers in cross-border customer-supplier relationships: The role of communication culture. Journal of International Marketing, 18(1), 63-85.

Johanson, J., \& Vahlne, J.-E. (1977). The internationalization process of the firm - a model of knowledge development and increasing foreign market commitments. Journal of International Business Studies, 8(1), 23-32.

Johnston, D. A., \& Wright, L. (2004). The e-business capability of small and medium sized firms in international supply chains. Information Systems and eBusiness Management, 2(2-3), 223-240.

Karagozoglu, N., \& Lindell, M. (2004). Electronic commerce strategy, operations, and performance in small and medium-sized enterprises. Journal of Small Business and Enterprise Development, 11(3), 290-302.

Karavdic, M, \& Gregory, G. (2005). Integrating e-commerce into existing export marketing theories: A contingency model. Marketing Theory, 5(1), 75-104

Katsikeas, C. S., Deng, S. L., \& Wartzel, L. H. (1997). Perceived export success factors of small and medium-sized canadian firms. Journal of International Marketing, 5(4), 53-72.

Kelly, D., \& Amburgey, T. L. (1991). Organizational inertia and momentum: A dynamic model of strategic change. Academy of Management Journal, 34(3), 591-612.

$\mathrm{Kim}$, Y. J., Song, J., \& Koo, C. (2008). Exploring the effect of strategic positioning on firm performance in the e-business context. International Journal of Information Management, 28(3), 203-214.

Knight, F. (1921). Risk, uncertainty, and profit. Boston and New York: Houghton Mifflin.

Kobrin, S. J. (1979). Political risk: A review and reconsideration. Journal of International Business Studies, 10(1), 67-80.

Kobrin, S. J. (2001). Territoriality and the governance of cyberspace. Journal of International Business Studies, 32(4), 687-705.

Kohn, T. O. (1997). Small firms as international players. Small Business Economics, 9(1), 45-51.

Lee, D., Kauffman, R. J., \& Bergen, M. E. (2009). Image effects and rational inattention in internet-based selling. International Journal of Electronic Commerce, 13(4), 127.

Lehdonvirta, V. (2009). Virtual item sales as a revenue model: Identifying attributes that drive purchase decisions. Electronic Commerce Research, 9(1-2), 97-113.

Lim, K. H., Leung, K., Sia, C. L., \& Lee, M. K. (2004). Is ecommerce boundary-less? Effects of individualism-collectivism and uncertainty avoidance on internet shopping. Journal of International Business Studies, 35(6), 545-559.

Lips, M., \& Koops, B.-J. (2005). Who regulates and manages the internet infrastrucure? Democratic and legal risks in shadow global governance. Information Polity, $10(1,2), 117-128$.

Lynne, M. (2000). Toward an integrative theory of risk control. In R. Baskerville, J. Stage, \& J. I. DeGross (Eds.), Organizational and social perspectives on information technology (pp. 167-174). Boston, MA: Kluywer Academic Publishers.

Magnússon, G. (1963). Production under risk. Uppsala: Almqvist \& Wiksells Boktryckeri AB.

Mascarenhas, B., \& Atherton, C. (1983). Problems in political risk assessment. Management International Review, 23(2), 22-30.

Mathur, I., \& Hanagan, K. (1981). Risk management by MNCs: The investors' perspective. Management International Review, 21(2), 22-37.

Miller, D., \& Toulouse, J.-M. (1986). Strategy, structure, CEO personality and performance in small firms. American Journal of Small Business, 10(3), 47-62.

Miller, K. D. (1992). A framework for integrated risk management in international business. Journal of International Business Studies, 23(2), 311-331.

Moini, H., \& Tesar, G. (2005). The internet and internationalization of smaller manufacturing enterprises. Journal of Global Marketing, 18(3,4), 79-94

Morgan-Thomas, A. (2009). Online activities and export performance of the smaller firm: A capability perspective. European Journal of International Management, $3(3), 266-285$.

Morgan-Thomas, A., \& Bridgewater, S. (2004). Internet and exporting: Determinants of success in virtual export channels. International Marketing Review, 21(4), $393-408$

Moscove, A. S. (2001). E-business security and controls. The CPA journal, 71(11), 40-45

Nagurney, A., \& Matsypura, D. (2005). Global supply chain network dynamics with multicriteria decision-making under risk and uncertainty. Transportation Research. Part E, Logistics \& Transportation Review, 41E(6), 585-612.

Nakos, G., \& Brouthers, K. D. (2002). Entry mode choice of SMEs in Central and Eastern Europe. Entrepreneurship: Theory \& Practice, 27(1), 47-63.

Oetzel, J. (2005). Smaller may be beautiful but is it more risky? Assessing and managing political and economic risk in costa rica. International Business Review, 14(6), 765-790.

Osborne, K. (1996). The channel integration decision for small- to medium-sized manufacturers. International Small Business Journal, 14(3(55)), 40-56

Pennathur, A. K. (2001). Clicks and bricks: E-risk management in the age of the internet. Journal of Banking \& Finance, 25(11), 2103-2123.

Penz, E. (2007). Paradoxical effects of the internet from a consumer perspective. Critical Perspectives on International Business, 3(4), 364-380.

Petersen, B., Welch, L. S., \& Liesch, P. W. (2002). The internet and foreign market expansion by firms. Management International Review, 42(2), 207-221.

Porter, M. E. (2001). Strategy and the internet. Harvard Business Review, 79(3), 62-78.

Prasad, V. K., Ramamurthy, K., \& Naidu, G. M. (2001). The influence of internet-marketing integration on marketing competencies and export performance. Journal of International Marketing, 9(4), 82-110.

Quelch, J. A., \& Klein, L. R. (1996). The internet and international marketing. Sloan Management Review, 37(3), 60-75.

Qureshi, I., Fang, Y., Ramsey, E., McCole, P., Ibbotson, P., \& Compeau, D. (2009). Understanding online customer repurchasing intention and the mediating role of trust-An empirical investigation in two developed countries. European Journal of Information Systems, 18(3), 205-222.

Rangan, S., \& Sengul, M. (2009). Information technology and transnational integration: Theory and evidence on the evolution of the modern multinational enterprise. Journal of International Business Studies, 40(9), 1496-1514.

Rasheed, H. S. (2009). Contrasting e-commerce business models: Performance implications for small enterprises. Journal of Developmental Entrepreneurship, 14(1), 89-101.

Reeves, J. (Ed.). (2000). Business risk. London: Caspian Publishing Ltd.

Rodríguez-Ardura, I., Meseguer-Artola, A., \& Vilaseca-Requena, J. (2008). Factors influencing the evolution of electronic commerce: An empirical analysis in a developed market economy. Journal of Theoretical and Applied Electronic Commerce Research, 3(2), 18-29.

Root, F. R. (1987). Entry strategies for international markets. Massachusetts: DC Heath and Company.

Rose, G., Khoo, H., \& Straub, D. W. (1999). Current technological impediments to business-to-consumer electronic commerce. Communications of the AIS, 1(16), $1-74$.

Rosenkranz, F., \& Missler-Behr, M. (2005). Unternehmensrisiken erkennen und managen. Heidelberg/Berlin: Springer Verlag.

Scott, J. E. (2004). Measuring dimensions of perceived e-business risks. Information Systems and E-Business Management, 2(1), 31-55.

Shrader, R. C., Oviatt, B. M., \& Phillips McDougall, P. (2000). How new ventures exploit trade-offs among international risk factors: Lessons for the accelerated internationization of the 21st century. Academy of Management Journal, 43(6), 1227-1247.

Sinkovics, R., \& Penz, E. (2005). Empowerment of SME websites: Development of a web-empowerment scale and preliminary evidence. Journal of International Entrepreneurship, 3(4), 303-315.

Soenen, L. A. (1979). Foreign exchange exposure management. Management International Review, 19(2), 31-38.

Stockdale, R., \& Standing, C. (2006). A classification model to support SME e-commerce adoption initiatives. Journal of Small Business and Enterprise Development, 13(3), 381-394.

Stray, S., Bridgewater, S., \& Murray, G. (2001). The internationalisation process of small, technology-based firms: Market selection, mode choice and degree. Journal of Global Marketing, 15(1), 7-29. 
Thong, J.Y.L. (1999). An integrated model of information systems adoption in small businesses. Journal of Management Information Systems, 15(4), 187-214. Vahlne, J.-E., \& Johanson, J. (2002). New technology, new companies, new business environments and new internationalisation processes? In V. Havila, M. Forsgren, \& H. Håkansson (Eds.), Critical perspectives on internationalisation (pp. 209-227). Amsterdam, NL: Pergamon.

Viehland, D. W. (2001). Managing business risk in electronic commerce. Paper presented at the Americas conference on information systems.

Vitale, M. R. (1986). The growing risks of information systems success. MIS Quarterly, 10(4), 326-334.

Wat, F. K. T., Ngai, E. W. T., \& Cheng, T. C. E. (2005). Potential risks to e-commerce development using exploratory factor analysis. International Journal of Services Technology and Management, 6(1), 55-71.

Welsh, J. A., \& White, J. F. (1981). A small business is not a little big business. Harvard Business Review, 59(4), 18-27.

Willcocks, L. P., Lacity, M. C., \& Kern, T. (1999). Risk mitigation in it outsourcing strategy revisited: Longitudinal case research at lisa. The Journal of Strategic Information Systems, 8(3), 285-314.

Winn, J. K. (2007). U.S. And EU regulatory competition and authentication standards in electronic commerce. International Journal of IT Standards and Standardization Research, 5(1), 84-102.

Wresch, W. (2003). Initial e-commerce efforts in nine least developed countries: A review of national infrastructure, business approaches and product selection. Journal of Global Information Management, 11(2), 67-79.

Wu, F, Mahajan, V., \& Balasubramanian, S. (2003). An analysis of e-business adoption and its impact on business performance. Journal of the Academy of Marketing Science, 31(4), 425-447.

Yamin, M. (2002). Subsidiary entrepreneurship and the advantage of multinationality. In V. Havila, M. Forsgren, \& H. Hakansson (Eds.), Critical perspectives on internationalisation (pp. 133-150). Oxford: Pergamon Press.

Yamin, M., \& Sinkovics, R. R. (2006). Online internationalisation, psychic distance reduction and the virtuality trap. International Business Review, 15(4), 339-360.

Yamin, M., \& Sinkovics, R. R. (2007). ICT and MNE reorganisation: The paradox of control. Critical Perspectives on International Business, 3(4), 322-336.

Zaheer, S., \& Manrakhan, S. (2001). Concentration and dispersion in global industries: Remote electronic access and the location of economic activities. Journal of International Business Studies, 32(4), 667-686. 